\title{
BUSINESS ENGLISH COURSE SYLLABUS FOR FUTURE EMPLOYEES OF MULTINATIONAL COMPANIES
}

Keywords: Business ENGLish COURSE, Syllabus, CULTURAL DiVERSity, INTERNATIONAL WORKPLACE, TEACHING LSP

\section{INTRODUCTION}

In the era of globalisation the need for teaching professional jargons is constantly growing because of the increasing volume of the international exchange and business contacts overseas. People no longer work in hermetically closed domestic markets, but spread to foreign ones, which "requires more interaction among people from diverse cultures, beliefs, and backgrounds than ever before" [Mazur, 2010: 5]. For this reason, there is growing demand for teaching English for Business Purposes (EBP) to answer to the educational market needs. However, the courses are rarely tailored for the specific needs of course participants, not only in terms of the linguistic part, but also in terms of the inclusion of cultural aspects.

At the tertiary level of education in Poland, academic teachers receive "few recommendations concerning the design of syllabi for foreign languages" [DzięciołPędlich, 2014: 83-84] from the Ministry of Science and Higher Education. Therefore, it is the teachers who design the courses of foreign languages which are based on the subject field the participants study. Moreover, in Poland students seldom participate in the process of the creation of the course of the foreign language learning and act as "its passive recipients" [Dzięcioł-Pędlich, 2014: 84]. For this reason, the course of the Business English at Linguistics for Business at the University of Łódź, was developed on the basis of the needs analyses, both from the employer and employee's perspective. Moreover, the communicative approach is used and during the classes cross-cultural issues are tackled, which leads to developing the "general linguistic awareness and communicative strategies" in the specialised discourse in 
order to prepare students for the international working environment [Gavrilova \& Trostina, 2014: 7].

\section{THE IMPACT OF CULTURAL DIVERSITY AT A WORKPLACE}

In multinational companies, people are not limited to work in homogenous environments but collaborate with people from various backgrounds. Then, we deal with cultural diversity which "is characteristic of groups of two or more people and typically refers to demographic differences of one sort or another among group members" [Ely \&Thomas, 2001: 230]. However, heterogeneity at a workplace may lead, on the one hand, to an increase in productivity and gaining the competitive edge for the company, but may also lead to conflicts, communication blockades among people and negative performance outcomes due to the culture clash, on the other. Moreover, the EU and the Polish government encourage companies to implement diversity management strategies which have proven that "attracting and retaining high quality employees from diverse backgrounds can bring tangible business benefits" [European Commission Justice, 2012: 13]. In order to do so, the EU implemented a special programme, i.e. the European Community Programme for Employment and Social Solidarity (2007-2013), called Diversity and Innovation, a Business Opportunity For All. Furthermore, the Society for Human Resource Management (SHRM), the world's largest association devoted to human resource management commissioned a study, whose findings will be incorporated "into future programming, including the SHRM Diversity and Inclusion Strategic Leadership Program; and use the knowledge gained to inform its global business strategy moving forward" [The Economist Intelligence Unit, 2009]. Therefore, there is a need to include and emphasise aspects of cultural diversity in the teaching process of business jargons in the curriculum in order for the students to "value multicultural differences in both associates and customers so that everyone is treated with dignity" [Mazur, 2010: 5].

\section{The Design of A Business English COURSE}

Employers expect the command of English from their employees since English has been treated as the language of international communication in business contexts. Therefore, university curricula include specialised language courses, i.e. EOP or EBP (English for Occupational Purposes and English for Business Purposes in particular) in order to educate students thoroughly. The EBP course should concentrate on the special linguistic needs of students: "the themes and topics related to business" [Widodo, 2007: 88] and to include cultural aspects to avoid unnecessary conflicts. In order to tailor the course to the students' needs, the design of the course should take account of students' expectations towards the BE course. The BE curriculum should also include cultural issues to sensitise learners to differences among cultures. Moreover, cultural diversity has become a hot issue nowadays, because "the European Commission encourages employers to put diversity management more firmly on their strategic business agenda" [European Commision Justice: 6]. 


\section{BACKGROUND INFORMATION OF THE BUSINESS ENGLISH COURSE}

\subsection{BUSINESS ENGLISH COURSE INFO}

The presented syllabus was designed for the Business English course taught in the second, third and sixth semester at the BA programme „Linguistics for Business" at the University of Łódź which comprises 84 teaching hours (28 hours per semester). Together with the General English (28 hours taught at the first semester) and Legal English (28 hours taught at the fourth semester) they exceed the University requirement for the English classes at the BA programme, i.e. 104 teaching hours.

\subsection{THE EXPECTED PROFILE OF THE L4B STUDENT}

The students at Linguistics for Business are expected to be general secondary school graduates whose required level of the language competence for English is B2 (in accordance to the requirements set by CEFR). The students are supposed to develop multilingual skills as they are to work in multinational companies or businesses where the command of foreign languages is a necessity.

\section{STUDENTS' NEEDS ANALYSIS}

At the beginning of the BE course, 50 first year students were selected at random in order to conduct the needs analysis. The purpose of the survey was to check students' expectations towards the contents of the course and the focus of the course on developing language skills in business contexts.

The results of the survey reveal a considerate variety as to experience and business contacts among the L4B students. 43 students have never participated in specialised language courses. The remaining 7 students consider courses at language schools or exam preparatory to be specialised. 29 respondents possess some prior working experience and 20 none. 18 out of 49 students had the opportunity to use English in specialised contexts. The circumstances included situations at the workplace: customer service, telephoning, financial audit, translation, English teaching or situations in private life, like insurance problems, plumbing, and lectures in English. 1 student did not respond to the question. 33 survey participants think their English is sufficient for communication, whereas 11 not (6 respondents did not provide the answer). The main areas of problems in the communication in English for the majority of respondents include terminology vocabulary, grammar, speaking, fluency, lack of skills or experience in formal writing. The survey also gauged the importance of the language skills. Table 1 presents the results of the students' expectations survey. 
TABLE 1. THE RESULTS OF THE STUDENTS' EXPECTATIONS SURVEY CONCERNING THE IMPORTANCE OF LANGUAGE SKILLS

\begin{tabular}{|l|c|c|c|c|}
\hline skill & reading & listening & speaking & writing \\
\hline very important & 7 & 25 & 47 & 20 \\
\hline important & 31 & 23 & 2 & 26 \\
\hline not very important & 10 & 2 & 1 & 3 \\
\hline unimportant & 2 & 0 & 0 & 1 \\
\hline
\end{tabular}

The results show that for 31 students reading skills are important and for 7 - very important. The vast majority of students, i.e. $25 \& 23$ consider listening to be very important and important. 46 course participants want to concentrate on writing and for almost all respondents speaking skills are of overriding importance and importance.

The questionnaire also checked how respondents feel about the usefulness of the selection of topics. Table 2 presents the results of the conducted survey.

TABLE 2. THE RESULTS OF THE STUDENTS' EXPECTATIONS SURVEY CONCERNING THE USEFULNESS OF TOPICS

\begin{tabular}{|c|c|c|c|c|c|c|c|c|c|c|c|c|}
\hline topic & & $\overrightarrow{0}$ & & 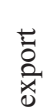 & & $\cong$ & & $\frac{\lambda}{2}$ & $\infty$ & 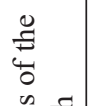 & $\tilde{0}$ & \\
\hline scale & $\sum_{\Omega}$ & 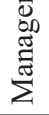 & 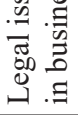 & 音 & 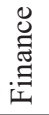 & 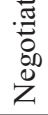 & 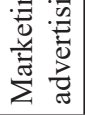 & $\begin{array}{l}\infty \\
\infty \\
\frac{0}{\tilde{N}} \\
\tilde{n}\end{array}$ & 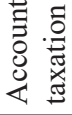 & 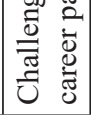 & 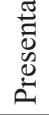 & 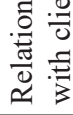 \\
\hline very useful & 12 & 23 & 14 & 4 & 16 & 33 & 24 & 13 & 13 & 10 & 21 & 36 \\
\hline useful & 28 & 22 & 28 & 10 & 22 & 13 & 19 & 23 & 16 & 21 & 18 & 10 \\
\hline of limited use & 8 & 4 & 9 & 30 & 10 & 4 & 5 & 10 & 18 & 14 & 10 & 3 \\
\hline not useful & 0 & 0 & 0 & 5 & 2 & 0 & 1 & 3 & 3 & 1 & 1 & 0 \\
\hline
\end{tabular}

Table 2 shows that the for the majority of respondents the selection of topics is either very useful or useful. However, import and export procedures were considered of limited usefulness, which is the most surprising. Workers with the command of English are often employed in logistics where they deal with the international exchange of goods. All topic areas are connected with the international communication with a high probability of dealing with people from other cultures. As a result, they include cultural issues in the process of learning Business English at L4B.

The respondents also had the opportunity to provide their own topic areas which include: social media, writing professional documents, relations in business, finance and accounting, IT terminology, business email writing, business meetings, logistics, cultural aspects, communication in business, motivation, networking, brands, law, negotiations (mentioned in the questionnaire), problems at work, real job scenarios, informal language at work, technology in business, politics and job interviews. The results of the survey were taken into account during the design stage of the Business English course at L4B. 


\section{THE DESIGN OF THE COURSE CONTENTS}

The course of Business English needs to be comprehensive and practical. For this reason, the course designer needs to take the opinions of different interests groups into account. The conducted students' expectations survey showed their areas of interest. However, the syllabus needs to reflect the needs of potential employers, too. As a result, the design contains the lists of topics given by the representatives of multinationals, and local businesses (gathered during the consultations) as well as it contains the most common topics from the local working environment. The syllabus was developed in accordance with the university policy concerning foreign language teaching. The underlying idea behind the creation of the Business English curriculum was to produce an all-embracing, communication-oriented method of teaching EBP to university students to provide them with effective linguistic means in the business for their future professional careers in multinational companies.

The course is focused on the four language skills, i.e. reading, listening, speaking and writing in business settings and covers a broad scope of business topics to provide the future employees of international companies with communicative skills to deal with professional issues.

It also takes cultural issues into account in order to sensitise students to different ways of doing business in different parts of the world to avoid culture clash and blunders.

\section{THE TOPICS OF THE LESSONS BE COURSE AT L4B}

The content of the course includes topics from different business areas. However, all topics are connected with the international exchange so they are connected with the cultural issues, which need to be emphasised.

TABLe 3. The topics of the Business English COURSE AT Linguistics for Business

\begin{tabular}{|c|c|}
\hline 1 & 2 \\
\hline \multicolumn{2}{|r|}{$2^{\text {nd }}$ Semester } \\
\hline HRM & Creating a professional CV and cover letter in English, job interview \\
\hline Franchising & Characteristic features, pros and cons of running a franchise \\
\hline Outsourcing & $\begin{array}{l}\text { Characteristic features, types of outsourcing and its use, opportunities } \\
\text { and threats }\end{array}$ \\
\hline Real estate & Types of real estate, documentation \\
\hline Logistics & Incoterms, import-export and EU documentation, EU procedures \\
\hline Banking and stock market & Types of assets: shares and bonds; forms of money \\
\hline Trends & Describing graphs and the interpretation of numerical data \\
\hline Negotiations & Negotiation strategies and negotiation practice \\
\hline \multicolumn{2}{|r|}{$3^{\text {rd }}$ Semester } \\
\hline Types of businesses & Forms of the formal organisation of companies \\
\hline Marketing & $\begin{array}{l}\text { Marketing mix, criteria of market segmentation, determining the target } \\
\text { customer }\end{array}$ \\
\hline
\end{tabular}


TABLE 3 (CONT.)

\begin{tabular}{|c|c|}
\hline 1 & 2 \\
\hline Advertising & $\begin{array}{l}\text { Types of advertisements, controversial practices of advertisers, } \\
\text { the successes and failures of advertising campaigns, creating a social } \\
\text { advertising spot }\end{array}$ \\
\hline Media and business & The role and impacts of social media in business \\
\hline Sales & $\begin{array}{l}\text { Customer service, dealing with telephone orders, complaints, business } \\
\text { correspondence }\end{array}$ \\
\hline Supply & $\begin{array}{l}\text { Factors of production, suppliers, supply strategies, business } \\
\text { correspondence }\end{array}$ \\
\hline E-marketing & Online shopping, advantages and disadvantaged of e-marketing \\
\hline Brands & $\begin{array}{l}\text { The importance of brands in commerce and for consumers, brand } \\
\text { management, creating a brand image }\end{array}$ \\
\hline Taxes & $\begin{array}{l}\text { Direct and indirect taxes, the effects of tax avoidance, different forms } \\
\text { of employment and taxation }\end{array}$ \\
\hline \multicolumn{2}{|r|}{$6^{\text {th }}$ Semester } \\
\hline Career path & $\begin{array}{l}\text { Difference between the career ladder and the career snake - holding } \\
\text { formal meetings }\end{array}$ \\
\hline Accounting & Basic concepts, audits and legal issues, types of assets \\
\hline Finance & $\begin{array}{l}\text { Trends in finance and banking, financial problems of international } \\
\text { companies }\end{array}$ \\
\hline Presentations & $\begin{array}{l}\text { Creating professional business presentations and strategies of making } \\
\text { presentations }\end{array}$ \\
\hline Cultural diversity & $\begin{array}{l}\text { Basic concepts: culture, time, distance; business etiquette and } \\
\text { communication }\end{array}$ \\
\hline Corporate entertainment & $\begin{array}{l}\text { Company events, creating good relations with customers during } \\
\text { outdoor events }\end{array}$ \\
\hline Relations with customers & Telephoning and mailing, customer service and solving problems \\
\hline Problems at work & $\begin{array}{l}\text { Sources of problems at work and ways of solving them, life balance } \\
\text { (between private and business life), stress management }\end{array}$ \\
\hline
\end{tabular}

The topics tackle problems and issues connected with the international exchange and different ways of doing business overseas. Most of them emphasise the cultural diversity in the workplace, so that the students become sensitive to existing differences and are prepared to do business with people of diverse cultural backgrounds.

\section{INTEGRATED SKILLS IN BUSINESS SETTINGS AS THE PREDOMINANT AIM OF THE COURSE}

The course aims at developing integrated communicative skills in business contexts and include cultural issues. The linguistic skills on which the course puts its emphasis are in agreement with the list in the Ordinance of the Minister of Science and Higher Education on the National Framework for Qualifications in Higher Education published in the Journal of Laws from 2011, No. 253, item 1520 (Dz.U. 2011, nr 253, poz. 1520). 
After completing the Business English course, the participant should possess the following skills (table 4).

TABle 4. The List SKills developed at the Business English Course AT LINGUISTICS FOR BUSINESS

\begin{tabular}{|l|l|}
\hline $\begin{array}{l}\text { Skills listed in the National } \\
\text { Framework for Qualifica- } \\
\text { tions in Higher Education }\end{array}$ & Skills developed at the Business English course \\
\hline H1A_W03, H1A_W05 & $\begin{array}{l}\text { Knowing basic terms in HRM, management, marketing, advertising, } \\
\text { finance, banking, accounting, logistics, negotiations, customer service } \\
\text { and creating company image in English }\end{array}$ \\
\hline H1A_U01, H1P_U13 & $\begin{array}{l}\text { Distinguishing, reading, comprehending and analysing the main } \\
\text { genres of specialised texts }\end{array}$ \\
\hline H1P_U11 & $\begin{array}{l}\text { Listening and comprehending specialised texts (distinguish } \\
\text { terminology and language functions) }\end{array}$ \\
\hline H1P_U01 & $\begin{array}{l}\text { Using correctly typical terminology from the domains mentioned } \\
\text { in point 1 in appropriate contexts }\end{array}$ \\
\hline H1A_U09, H1P_U13 & $\begin{array}{l}\text { Individually using terminology and phrases necessary in } \\
\text { specialised oral communication (pragmatic aspects of specialised } \\
\text { communication) }\end{array}$ \\
\hline H1A_U08, H1P_U12 & Creating selected business texts in English \\
\hline $\begin{array}{l}\text { H1P_K02, H1P_K04, } \\
\text { H1P_K05 }\end{array}$ & $\begin{array}{l}\text { Developing the following attitudes: openness to cultural varieties, } \\
\text { sensitivity to other ways of doing business in different cultures }\end{array}$ \\
\hline H1P_U14 & $\begin{array}{l}\text { Developing and maintaining a linguistic competence of English } \\
\text { at the level B2 (according to CEFR) }\end{array}$ \\
\hline
\end{tabular}

One of the target skills includes developing a desired attitude towards cultural differences (skills H1P_K02, H1P_K04, H1P_K05), which might be helpful in students' future professional careers.

\section{Teaching Methods}

The Business English course is based on two basic teaching methods: expository and practical both of which are to provide necessary linguistic means to communicate effectively in business settings.

Expository methods are in the form of informative lectures and discussions which are illustrated with audiovisual input preceded by elements of distance learning (students receive handouts before classes). New business terms and issues that arise and appear during the classes are also explained.

Practical classes and exercises on the subject comprise the practical methods. They include group work, simulation games, case studies, discussions, project work and brainstorming.

\section{ASSESSMENT CRITERIA OF STUDENT'S PERFORMANCE}

Students are assessed on the basis of different criteria. First of all, the students need to take an active part in exercises (during classes students need to answer 
questions, discuss, argue and use a target foreign language). Secondly, students are to hand in 2 written projects connected with the topics (practical applications of terminology and theoretical knowledge gained during classes), graded on the 2-5 scale. Thirdly, students' progress is assessed by three progress tests, testing their knowledge of terminology and specialised knowledge gained during classes in the form of open and closed tests. The borderline of passing is 50\% minimum. The final grade is the average of all grades gathered during the whole semester.

\section{Conclusion}

Cultural diversity has become a widely discussed issue as companies have been expanding their operation to foreign markets. Dealing with people from different cultural backgrounds might be challenging and motivating on the one hand, on the other the culture clash might hinder the company's performance. Therefore, developing sensitivity to cultural issues at foreign business language courses has been seen as a necessity. As a result, the Business English course at Linguistics for Business was designed in such a way so as to include cultural issues in the curriculum.

The syllabus takes account of results of the students' expectations survey, needs analysis conducted among potential target employers (after consultations with business representatives), and analysis of the most common topic areas from the local business. It was created in accordance with the university policy as well as the Ordinance of the Minister of Science and Higher Education on the National Framework for Qualifications in Higher Education. The overall aim of the course is to create an all-embracing, communicative method of training English in business contexts (EOP) for future employees of multinational companies and businesses with contacts overseas and develops all language skills, i.e. reading, listening speaking and writing in business contexts. In order to fulfil its aim, the course covers a wide scope of business topics from different areas to anticipate particular needs of future employers and make students aware of the cultural diversity they are to encounter.

\section{REFERENCES}

Chiappini F.B., Nickerson C., Planken B. [2007], Business Discourse, Palgrave Macmillan, London.

Dzięcioł-Pędich M. [2014], Business English in the Eyes of Economics and Management Students at the University of Bialystok, Studies In Logic, Grammar and Rhetoric, Vol. 38 (51), pp. 83-102.

The Economist Intelligence Unit [2009], Global Diversity and Inclusion Perceptions, Practices and Attitudes. A Study for the Society for Human Resource Management (SHRM), Alexandria, USA: SHRM Office of Diversity \& Inclusion Initiatives. 
Edwards N. [2000], Language for business: effective needs assessment, syllabus design and materials preparation in a practical ESP case study, English for Specific Purposes, Vol. 19, pp. 291-296.

European Commission Directorate-General for Employment, Industrial Relations and Social Affairs [2003], The Costs and Benefits of Diversity. A study on methods and indicators to measure the cost-effectiveness of diversity policies in enterprises, Centre for Strategy and Evaluation Services, Kent.

European Commission Justice [2012], Realising the business benefits with European diversity charters. Managing Diversity at Work, Publications Office of the European Union, Luxembourg.

Gavrilova E., Trostina K. [2014], Teaching English for Professional Purposes (EPP) vs. Content and Language Integrated Learning (CLIL): the Case of Plekhanov RussianUniversity of Economics (PRUE), European Scientific Journal /SPECIAL/ edition, Vol. 2, pp. 7-17.

Mancho-Barés G., Llurda E. [2013], Internationalization of Business English communication at university: A threefold needs analysis, Ibérica, Vol. 26, pp. 151-170.

Mazur B. [2010], Cultural Diversity in Organisational Theory and Practice, Journal of Intercultural Management, Vol. 2, No. 2, pp. 5-15.

Sim M.A. [2012], Ups and Downs of Teaching Business English Terminology, The Round Table. Partium Journal of English Studies, Retrieved from: http://www. theroundtable.ro [access: 04.03.2015]. 